Historic, Archive Document

Do not assume content reflects current scientific knowledge, policies, or practices. 


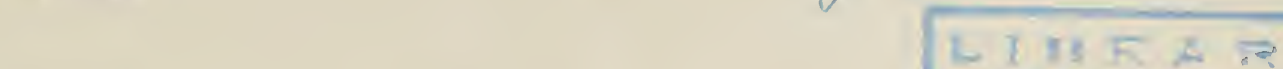
\begin{tabular}{l|l|l|}
1914 & SPRING AND FALL & 1914 \\
\hline
\end{tabular}

\section{CATALOGUE AND PRICE LIST \\ OF THE \\ ALPHA NURSERY}

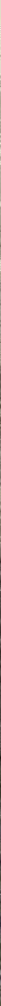

GEO. G. and H. G. WIRT, Proprietors

\section{ALPHA, ILLINOIS}

Our aim is to grow only the very best, most hardy and productive varieties suitable to this climate of fruit trees and plants in the very best possible manner. 


\section{General Information}

Orders should be sent in early on a separate sheet from letter.

FREIGHT-We will pay the freight to your nearest railroad station on all orders of $\$ 5$ or over, east of Colorado, except on large shade trees.

CLUB ORDERS-If you do not wish $\$ 5.00$ worth, get your neighbors to club with you and we will tie and label each order separate and ship together and pay the freight.

TERMS-Cash or satisfactory reference from unknown parties before shipment. Six at dozen rates, 50 at 100 rates.

PACKING-These prices are for stock well packed and delivered at the railroad station here.

MISTAKES cheerfully corrected, but no claims allowed unless made within seven days after the stock is received.

WE WARRANT ALL STOCK TRUE TO NAME with the agreement that should any not prove true we will return the money paid for said stock, or replace with stock that is; but are not liable for damamges other than herein named.

QUALITY-Our nursery stock is the very best that can be grown, and up to the standard in every way. We are entirely responsible; we own our nursery and farm, also other property.

PARCEL POST-The rate on plants is 8 cents per pound.

PLANTING-Cut all side limbs back to two or three buds and shorten the top; make the holes plenty large so as not to crowd the roots and plant at the same depth as they grew in the nursery. See that the roots are well spread out; use surface soil for filling, pressing it firmly around them; do not hurry the job; do it well and success is certain. Trees and plants should not long be exposed to the sun and air. Never put manure in the holes next to the roots, it causes decay. Plant strawberries with spade or dibble; spread roots out fan shape.

\section{Proper Distances Between Trees and Plants}

Apples ............. Raspberries by $30 \mathrm{ft}$. R....... by $8 \mathrm{ft}$. Pears ............20 by $20 \mathrm{ft}$. Blackberries ........ 2 by $8 \mathrm{ft}$. Plums .............16 by $16 \mathrm{ft}$. Strawberries and Asparagus

Peaches ............16 by $16 \mathrm{ft} . \quad 18$ in. in rows $4 \mathrm{ft}$. apart Cherries ............16 by $16 \mathrm{ft}$.

The number of plants required for an acre may be ascertained by dividing the number of square feet in an acre $(43,560)$, by the number of square feet given to each plant.

Urbana, I11., Aug. 7, 1913

This is to certify that the growing nursery stock and premises of George Wirt, situated at Alpha, Illinois, have been inspected by J. H. Gage, a duly appointed inspector of this office, and that said nursery and premises are apparently free from the San Jose scale and other dangerous insects and dangerous plant diseases.

This certificate applies only to the condition of this nursery for the year ending Aug. 5, 1914.

No. 16

S. A. FORBS, State Entomologist

REFERENCES: Alpha State Bank or any business house in Alpha. 


\section{APPLES}

Six apples of extra high quality, Jonathan, Winter Bannana, Stayman's Winesap, Delicious, Grimes Golden, and Mammoth Black Twig. These are the very best of the apples, and they all do well here. They cover the season from November to May. We will deliver one each of the above trees, which are No. 1 stock, 4 to 6 fect, to any address for $\$ 1.20$, while our surplus lasts.

\section{APPLES \\ 4 to $6 \mathrm{ft}$., 25 cents each; 6 or more, 20 cents each. \\ SUMMER VARIETIES}

Benonia-Medium, roundish, pale yellow, shaded with crimson; juicy, tender, sub-acid. August.

$\checkmark$ Early Harvest-Medium to large, roundish, bright straw color, flesh white. July.

Astrachan Red-Large, roundish, nearly covered with crimson; juicy, sub-acid; tree strong, spreading grower, good bearer. August.

Red June-Medium, oblong, hardy and productive; deep red color; flesh white, with tender, rich sub-acid. August.

Yellow Transparent-Medium, yellow, good quality, productive, excellent; bears early. July.

\section{AUTUMN VARIETIES}

Duchess-Large size, roundish, streaked with red and yellow; flesh white, juicy, acid. September.

Famuese (Snow)-Medium, deep crimson; flesh snowy white, tender. November.

Golden Sweet-Fruit large, pale yellow; flesh tender, sweet and rich; hardy and a good grower. August and September.

Wealthy-Large, roundish, smooth, nearly covered with dark red; flesh white, fine juicy, sub-acid, quality very good; good grower and productive. October.

Wolf River-Very large, redish striped; flesh coarse; tree very hardy and strong grower. October.

\section{WINTER VARIETIES}

Ben Davis-Large, handsome, striped; good, hardy, vigorous and productive; late keepers, very showy. December to March.

$\checkmark \quad$ Baldwin-Medium size, red; flesh yellow, sub-acid; tree a good grower, but a little tender here. December.

$\checkmark$ Domine-Medium size, greenish yellow, good quality. January.

$\checkmark$ Delicious-Medium size, red, excellent quality; good grower and hardy. December to Marcli. Not over six sold in one order.

$\checkmark$ Gano-Good size, smooth and very attractive; decp red, resembles Ben Davis, but is an improvement on that variety, being handsomer and better colored. December to March.

$\checkmark$ Grimes Golden Pippin-Medium, golden yellow, with white dots; crisp, tender and juicy, excellent; tree vigorous, hardy and productive. November and January.

$\checkmark$ Jonathan-Medium, red and yellow, very showy, juicy, excellent; tree slender and spreading; bears early. November to February.

Jenet-Small size, greenish yellow; very late keeper.

Mammoth Black Twig-Large, deep red, sub-acid; early and abundant bearer, keeps well; tree a strong grower, resembles Winesap, but is superior in many ways, and fully one-third larger. January to April. 
Northwestern Greening-Large, smooth, greenisli yellow; flesh finc grained, firm; extremely hardy and a strong, handsome grower. December to April.

Paradise Sweet-Medium size, greenish yellow, sweet, good quality. December.

Russet-Medium size; flesh greenish white, good quality; tree a good grower and hardy. January.

Stayman's Winesap-Fruit large, striped, nearly covered with red; flesh greenish yellow, very juicy and aromatic; very good; tree hardy and a strong, spreading grower; a good, early bearer; the best of our late winter apples. January to May.

Salome-Medium, yellow and red, very handsome; flesh whitish yellow, tender, slightly aromatic; tree hardy, vigorous, upright grower. January to May.

Seedless-Tree a good grower and hardy; fruit medium size, yellow, with red stripes.

Tallman Sweet-Medium, pale ycllow, firm, rich and very sweet; the most valuable, preserving and baking apple; vigorous. October and December.

Winter Bannana-Fruit large, color clear yellow, overspread with pink; red-blushed; flesh yellow, very rich and juicy; tree a good grower; begins bearing very young. November to January.

Winesap-Medium, roundish, deep red, firm, crisp, juicy; excellent quality, moderate grower and good bearer; succeeds well throughout the West; very profitable. December to May.

Yellow Bellfower-Large sizc, pale yellow; flesh white, sub-acid; tree a good grower; rather shy bearer. December.

\section{CRAB APPLES}

\section{5 cents each}

Hyslop-Dark crimson, with bloom; very showy and popular.

Transcendant-Large, yellow striped with red.

\section{CHERRIES}

\section{4 to $6 \mathrm{ft}$., 35 cents; 6 or more, 30 cents each}

Early Richmond-Medium, red, carly, hardy, immensely productive; ripens last of June.

Montmorency-Large; fruit beautiful dark red, sub-acid; of the very best quality; ten days later than the Early Richmond; a fine shaped tree; hardy and productive.

\section{PEARS}

\section{4 to $6 \mathrm{ft} ., 35$ cents; 6 or more, 30 cents each}

Bartlett-Large size, color rich yellow, with often a beautiful blush next the sun; buttery, very juicy, and highly flavored. September.

$\checkmark$ Duchess-Very large; dull, greenish yellow, streaked and spotted with russet; flesh white, buttery and very juicy, with a rich and very excellent flavor. October.

C Keifer-A vigorous grower, and an early bearer; very productive; fruit large, golden yellow, with red cheek. October.

Lincoln-Tree hardy, strong grower; flesh fine, very sprightly, rich, juicy. August.

Dwarf Pears-Bartlett, Duchess and Lincoln. These pears commence bearing much earlier than the standards. 4 to $5 \mathrm{ft}$., 30 cents each; 6 or more, 25 cents each.

Quinces-25 cents each; $\$ 2.50$ per 12. 


\section{PEACHES}

4 to $6 \mathrm{ft}$., 25 cents each; 6 or more, 20 cents each

Alexander-Medium size, nearly round; skin, greenish white, nearly covcred with deep red; flesh white, juicy and sweet, adhering slightly to the stone. July 20th.

Champion-Fruit large, delicious, sweet, juicy, best quality of all early varieties, skin, creamy white, with red cheek; handsome, hardy and productive and a good shipper; adhering slightly to the stone. August 15th.

Crosby-Freestone, medium size, bright yellow, streaked with carmine; annual bearer; hardy. September 15th.

Elberta-Freestone, very large, yellow, with red cheek, juicy and high flavored; flesh yellow; an excellent shipping variety. September 5th.

Crawford's Early-Freestone, large yellow; flesh yellow, quality extra gond; tree good grower, but the buds are tender. September.

Crawford's Late-Freestone, very large, roundish, red cheek; flesh yellow and rich; poor bearer here. October.

Lemon Cling-Very large, light yellow; flesh firm, yellow and rich; the great canning peach of the South and WVest. August.

\section{PLUMS}

4 to $6 \mathrm{ft}$., 35 cents each; 6 or more, 30 cents each

Abundance-Medium size, showy, beautiful amber colored, turning to a rich cherry, highly perfumed; flesh, light yellow, exceedingly juicy and tender. July.

Burbank-Very large, redish purple; flesh yellow and solid; cling, fine quality, one of the best for canning; tree, strong, spreading grower, hardy and productive; subject to rot in wet years. August.

Red June-A vigorous, hardy, upright, spreading tree; as productive as Abundance. Fruit medium to large, deep vermillion-red with handsome bloom; very showy; flesh, light lemon color, slightly sub-acid, of good and pleasant quality; pit small. Early.

Wild Goose-Hardy, native, deep red with purplish bloom; flesh yellow, juicy and sweet; rapid grower, early and abundant hearer. July and August.

Blue Damson-Fruit small size, rather tart, good quality; dark purple, covered with a blue bloom; productive. September.

Yellow Egg-Fruit large, yellow, fair quality; fine for canning; tree a good grower and very productive; the best of the yellow plums for this climate. September.

Guii-Fruit large, purplish blue; flesh yellow, firm and sweet; freestone; tree hardy and a strong grower. It has done the best here of any of the large blue plums. September.

\section{CHESTNUTS}

Paragon (Sobers)-The most widely planted and most uniformly successful variety yet cultivated in the United States. The three or more broad, thick, handsome nuts in each burr are of extra large size and quality. The tree makes a strong growth, bears early and abundantly, often bearing the second year from graft. Trees four years old, from graft, have produced one bushel each. Seedlings do not come true, but they bear fine nuts. Parties wishing any of these trees should order as early as possible.

Grafted trees, three or four years old, $31 / 2$ to $6 \mathrm{ft}$., $\$ 1.00$ each. each.

Seedlings, two years old, 2 to $3 \mathrm{ft}$., from nuts of grafted trees, 35 cents

American Sweet-The nuts of this tree form quite an item in our commerce. They are sweet and delicately flavored. This chestnut is also a grand timber and ornamental shade tree. 4 to $5 \mathrm{ft}$., 35 cents each. 


\section{GRAPES}

Strong, healthy vines. 10 cents each; $\$ 1.00$ per $12 ; \$ 5.00$ per 100 .

Campbell's Early - A strong grower, hardy and very early; an abundant bearer; bunches and berries very large, glossy black color; pulp sweet and juicy, with few seeds; ripens with the Moore's Early, but will hang on the vines until frost. We have kept them in baskets in fine condition until December.

Moore's Early-Black, bunches medium size and very compact; berries large and of excellent quality; ripens ten days before Concord, which makes it very desirable for market; very hardy, well suited for the North; one of the best.

Concord-Black, the most popular grape in America; bunches and berries large, hardy, healthy and productive.

Agawam-Red or maroon color; berries large, of rich, peculiar aromatic flavor; ripens about with Concord; a good keeper; vine a strong, rank grower.

Luti-Dark red, bunch and berry medium; flesh and pulp sweet; vine very hardy, vigorous and productive; ripens about with Moore's Early.

Moore's Diamond-White, bunches and berries large; flesh tender, juicy, hardy, productive, early; fine quality.

We have a small stock of the following varieties at 10 cents each: Wyoming Red, Worden Black, Lindley Red, Woodruff Red, Niagara White, Pocklington White, Eaton Black, Green Mountain White, Brighton Red, Delaware Red.

\section{STRAWBERRIES}

The following varieties of strawberries are all perfect flowering; that is. they do not need any other variety planted near them for fertilizer. We tie all strawberries 25 in a bunch, except the Everbearing and Norwood. If the plants are to be sent by mail add at the rate of 20 cents per hundred.

We have a large stock of plants of the Senator Dunlap, but a light stock of other varieties. All plants will be taken from new beds, where we dig up the whole row. They are all strong and healthy plants. Prices: Senator Dunlap, 25 plants, 25 cents; 50 plants, 35 cents; 60 cents per 100 ; $\$ 2.50$ per $500 ; \$ 4.00$ per 1,000 .

Gandy, Glen Mary, Brandwine, August Luther, 30 cents per 25; 40 cents pér $50 ; 75$ cents per 100 .

Senator Dunlap-Fruit good size, regular form, beautiful bright red; glossy, firm, splendid keeper and shipper; excellent quality; one of the best for canning; ripens early and continues a long time.

We consider the Dunlap the best berry that grows. It and the Gandy will cover the season from early to late.

Gandy-Extra large and handsome, firm, high quality; the very latest; most all of the crop ripens after the Dunlap.

Glen Mary-A large berry of good quality; deep red all the way through; a sweet, rich flavor; the plants are vigorous and productive.

Brandwine-A large, late berry, with strong, healthy foliage; first berries very large, balance small.

August Luther-An extra early berry, of good quality; a strong grower and productive.

Norwood-Extra large and of very fine quality; bright red all the way through, a strong, healthy grower; the best of the large fancy berries, 6 plants, 20 cents; 12 plants, 35 cents; 25 plants, 60 cents.

\section{EVERBEARING STRAWBERRIES}

6 plants, 30 cents; 12 plants, 50 cents; 25 plants, 80 cents

Americus-Berries medium size, bright red and extra good quality; plant a strong, healthy grower and very productive. We consider this the best of the Everbearers.

Pan American-Very much like the above, except the berries are smaller, and the plant is not as gond grower. 


\section{RASPBERRIES}

35 cents per $12 ; \$ 1.50$ per $100 ; \$ 5.00$ per 500

Cumberland-One of the largest black raspberries known; has been well tested in nearly all sections, giving thorough satisfaction; in liardiness and productiveness it is unexcelled; the quality is the very best; the fruit is firm and will stand long shipments. It commences to ripen in mid-season and continues a long time; the bush is healthy and vigorous.

Columbian-Deep, purplish red and highly flavored, extra strong cances, wonderfully productive, berry large.

Loudon-The best red rasplberry, productive, large size, bright color, very hardy.

Everbearing Red Raspberry (St. Regis)-12 plants, 50 cents; 25 plants, 90 cents. The earliest of all; wonderfully productive; gives a crop of fruit all summer and autumn; fruit on old canes until August, when berries commence to ripen on the new canes; berries bright crimson, of large size and unsurpassed quality; canes stocky, strong grower.

\section{BLACKBERRIES}

Eldorado-Among the good points of this valuable new blackberry are great productiveness, hardiness, extra fine quality, and sweetness of flavor, without core, the berrics are large, jet black, borne in clusters and ripen well together; sweet, melting, rich and pleasant to the taste. Price, 35 cents per dozen; $\$ 2.00$ per 100 .

\section{GOOSEBERRIES}

Champion-A new variety introduced from Oregon, where it originated. Bush a strong, upright grower, very hardy and enormously productive; fruit round, entirely free from mildew and easily gathered. IVe have tested most all varieties and discarded them, as they were so much inferior to the Champion. 15 cents each; $\$ 1.50$ per $12 ; 2$ years oll.

\section{CURRANTS}

\section{Large 2 year, 10 cents each; $\$ 1.00$ per 12}

Pomona-Fruit clear, bright red, almost transparent; has but few small seeds; hangs on a long time after ripe; vigorous, healthy, hardy, most produrctive; quality best; good shipper.

$\sqrt{ }$ Cherry-The largest of the red currants, strong, stocky bush; hardy, and moderate productive.

Black English-Largest and best of the blacks.

White-A good grower; berries yellowish white, sweet and mild.

\section{PIE PLANT}

Linnaeus-Large, early, tender and fine; the very best of all. 10 cents each; $\$ 1.00$ per 12 .

\section{ASPARAGUS}

25 cents per $12 ; \$ 1.00$ per $100 ; \$ 3.00$ per 500

Conover's Colossal-Produces large, tender shoots of vigorous growth.

\section{EVERGREENS}

Arbor Vitae-The best for hedges. 18 to 24 inches, 25 cents each; 12 to 18 inches, 10 cents each, any number.

Norway Spruce-The best for windbrakes. 2 to $3 \mathrm{ft}$., 35 cents each; $\$ 3.00$ per dozen; 18 to 24 inches, 25 cents each; $\$ 2.40$ per $12 ; 12$ to 18 inches, 10 cents each, any 11 umber.

Red Cedar -4 to $6 \mathrm{ft}$. Nice specimens, 40 cents each; $\$ 3.50$ per 12 ; 3 to $4 \mathrm{ft}$., 30 cents each; $\$ 2.50$ per 12 .

White Pine-2 to $3 \mathrm{ft}$., 35 cents each. 
Balsam Fir-Dark green, nice for the lawn. 2 to $3 \mathrm{ft}$., 35 cents each; 18 to 24 inches, 25 cents each.

We have a screen of arbovitea $64 \mathrm{ft}$. long and $7 \mathrm{ft}$. high, containing 38 well branched trees; they make a thick, even screen. We would dig them with a ball of earth and burlap, and deliver on car here for $\$ 50.00$.

\section{ORNAMENTAL TREES}

Popular Carolina-One of the most rapid growing trees, with large, deep green leaves; succeeds everywhere, especially adapted to cities, where it makes a fast growth, and resists smoke and gas. It makes a spreading head and dense shade when properly trimmed. There are more of them used for street planting than any other tree. 5 to 6 feet, 25 cents each; $\$ 2.00$ for 12; $\$ 15.00$ per 100 .

Elm-White, the noble, drooping, spreading tree of our woods; one of the grandest of park or street trees. 5 to $6 \mathrm{ft}$., 25 cents each; $\$ 2.40$ per 12 .

Birch, White-A tree with graceful, airy foliage and white bark, desirable for lawns. 5 to $6 \mathrm{ft}$., 25 cents each.

Mountain Ash-A very pretty, small sized tree, with clusters of large orange berries in the fall. 5 to $6 \mathrm{ft}$., 25 cents each.

Hard Maple-Spreading top and very dense shade, but slow grower. 4 to $5 \mathrm{ft}$., 25 cents each; 5 to $6 \mathrm{ft}$., 35 cents each.

Catalpa Speciosa-This valuable tree is a rapid grower, with very large, light green leaves, with large white flowers in June. 4 to $5 \mathrm{ft}$., 20 cents each; $\$ 2.00$ per 12 ; 5 to $6 \mathrm{ft}$., 25 cents each; $\$ 2.40$ per $12 ; 3$ to $4 \mathrm{ft}$., $\$ 5.00$ per 100 .

Catalpa Seedling- $\$ 1.00$ per $100 ; \$ 3.00$ per 500 . These are the hardy Speciosa. For posts they should be planted $4 \times 4$ feet, and given good cultivation for two or three years. This is very important to get a straight, strong growth. The government report claims they will last as long as red cedar or herlge, and should make good posts in half the time.

\section{WEEPING TREES}

Catalpa Bungeii (Umbrella Catalpa)—Grafted on stems six to eight feet high, it makes an umbrella-shaped top without pruning; perfectly hardy; leaves large, glossy, heart-shaped, deep green; lay like shingles on a roof. $\$ 1.00$ each.

\section{BIRCH}

Cut Leaved Weeping-Erect, stately, rapid, hardy, with long, fine penlant branches and delicately cut leaves; the trunk very white; no tree more elegant for the lawn or yard. Undoubtedly the most popular of all weeping trees. 5 to $6 \mathrm{ft}$., $\$ 1.00$ each.

\section{MULBERRY}

Tea's Weeping-A variety of the well known Russian Mulberry. Forms a perfect umbrella-shaped head, with long, slender branches which droop to the ground parallel with the stem. Very beautiful and hardy. $\$ 1.00$ each.

\section{WILLOW} each.

Kilmarnock Weeping-An exceedingly graceful tree, very hardy. 75c

\section{SHRUBS}

\section{5 cents each, two years}

Almonds, Double Flowering-Dwarf, pink flowers like small roses, very double; early; profuse.

Barberry Thunbergii-A very pretty variety from Japan, of dwarf, graceful habit; foliage small, changing to beautiful bright red early in the fall; very showy.

Calycanthus (Sweet Scented Shrub) - The wood is fragrant, foliage rich; flowers are of chocolate color, having a peculiarly agreeable odor. Flowers in June and at intervals afterwards.

Hardy Hydrangia-This is one of the most valuable hardy shrubs. It attains a height of three or four feet, and is perfectly hardy in all parts of the country. The flowers are white, borne in immense panicles nearly a foot in length. It commences flowering in July and continues until November. 
The plant should be cut back every spring at least one-half of the season's growth, as the flowers are borne on the new wood.

Lilac, Purple-A standard variety, always good, profuse bloomer.

White-A well known white lilac; flowers slightly cream colored.

Snowberry-1 very pretty bush, with clusters of rose-colored flowers early in the spring, followed by waxy white berrics, which hang on through part of the winter.

Snowball-A magnificent old favorite, tall growing shrub with very showy pure snow white flowers, produced in large ball.

Syringa-Of vigorous habit, very hardy, with large, handsome foliage and beautiful white flowers.

Spirea Van Houtei-(Bridal Wreath). The most beautiful of all Spireas, an immense bloomer; pure snow white flowers; early; hardy.

Spirea Ballardi-Rose colored flowers in large spikes; blooms all summer; grows four fect high.

Spirea Anthony Waterer-Dwarf; this beautiful variety produces flowers of bright crimson and blossoms so freely that it may be kept flowering through the summer till late fall by trimming away the dead flowers. In growth it makes a large, round head, one to two fect high.

Yucca-A tropical looking plant, with long, narrow leaves; the flower stalks rise from the centre about three feet high, and are covered with creamy, white bell-shaped flowers, forming a perfect pyramid; perfectly hardy, the leaves staying green all winter. Strong two year plants, 25 cents cach: $\$ 2.00$ per dozen.

Sumac (Cut Leaf) - 1 very striking plant of moderate size, with deeply cut leaves resembling fern leaves, dark green above and glaucous below and turning to a rich red in attumn.

Deutzia-Blooms in carly spring, in large panicles; pure whitc.

Golden Glow-Flowers are produced on long stems in large quantitics, and resemble golden yellow cactus dalies.

\section{HEDGES}

American Arbor Vitea-1 native of the North; very hardy and easy to transplant and will stand shearing well any time of the year; the most popular for hedges and screens, as it keeps green the year round. 12 to $18 \mathrm{in}$. transplants, 10 cents each, any quantity.

Barberry Thunbergeri-From Japall, of dwarfish habit; small foliage that turns to a scarlet in the fall; small flowers in June that turn to scarlet berries that last through the winter; perfectly hardy; it makes a very pretty hedge. 12 to 18 inches, 10 cents each, any quantity.

Privit, Amors-Harly, a valuable shrub for hedges and borders; foliage glossy green; holds its color almost the whole year. Will stand shearing almost to any extent; very hardy. 12 to 18 inches, 7 cents each, any quantity.

Privit, California-Very much like the above, but more tender. 12 to 18 inches, 5 cents each, any quantity.

Hedges should be planted one foot apart in the row, and kept well cul. tivated or heavily mulched for two years.

\section{CLIMBING PLANTS}

Honeysuckle, Scarlet Trumpet-One of the handsomest in cultivation, coral flowers; very vigorous and hardy; blooming all summer. 25 cents each.

Wisteria, Purple-One of the finest climbers, of rapid growth, and perfectly hardy, with long, pendulous clusters of bluish purple. Flowers in June. 25 cents each.

Boston Ivy (veitchii) - It grows rapid and clings to the smoothest surface; the foliage is very handsome in the summer and changes to scarlet in autumn; when once established it is quite hardy; it needs some protection the first year. 25 cents each.

American Ivy-The well known native vine with the five parted leaves, that change to rich crimson in autumn; berries blue black; very rapid grower and perfectly hardy. 25 cents each. 


\section{CLEMATIS}

\section{2 years}

Jackmanii-A very profuse blooming variety, with flowers from four to six inches in diameter; of an intense violet purple color, borne successionally in continuous masses on the summer shoot. 50 cents each.

Henryii-Large, pure white flowering. 50 cents each.

Paniculata-New. A strong, vigorous grower; very free flowering; pure white; unusually fragrant. 35 cents each.

\section{PAEONIES}

Paeonies-A gorgeous flower; the dark, green leaves are at all times very attractive; hardy as an oak, and once planted will take care of themselves. Colors, Light Pink, Dark Pink, Dark Red late, Bright Red carly, and White. 25 cents each.

\section{ROSES} noted.

Everblooming Hybrid Perpetuals. 25 cents each, 2 years except as

Coquette Des Blanches-Pure white, very beautiful. We think this is the best pure white hybrid Perpetual.

General Jacqueminot-Brilliant velvety crimson; large, showy, and a fine grower; a magnificent variety.

Magna Charta-A general favorite, prized on account of its strong, upright growth and bright, healthy foliage. as well as for its magnificent bloom. The color is a beautiful bright pink.

Paul Neyron-Deep, shining rose, very fresh and pretty. Flowers large, often measuring five inches in diameter. The buds always develop fine, perfect roses.

American Beauty-A hardy rose, of the largest size, having the everblooming qualities of the tea roses; it is the sweetest of all roses; the color is a decp, brilliant red, shaded to a rich carmine. 35 cents cach.

Everblooming Rose-Always bloom on the new growth, and should bc cut off six inches above the ground when planted, and again each fall after the leaves have fallen and well covered with leaves.or grass.

\section{CLIMBING ROSES, 25 CENTS EACH, 2 YEAR}

Crimson Rambler-It is a vigorous grower; flowers glowing crimson and produced in immense panicles.

Flower of Fairfield-Everblooming Crimson Rambler, it blooms on the old wood early and follows up on the new growth until late in the fall. 35 cents each.

Blue Rambler (Veilhenblau)-The flowers are a violet blue; the buds show some red, but quickly change as they open.

Dorothy Perkins-Beautiful shell pink, full and double; large size for a cluster rose; it is a hardy, strong grower.

Prairie Queen-The flowers are very large and of peculiat globular form; bright, rosy red, changing to lighter as the flower opens. Of strong, rapid growth.

Baltimore Belle-Pale blush, variegated carmine rose and white.

Tube Roses-Double, white, very fragrant and hardy. 10 cents each; 75 cents per 12 .

Lily of the Valley-Small, white flowers, very fragrant. 5 cents each; 40 cents per 12 .

\section{SOUDAN GRASS}

\section{5 cents per package; 3 for 10 cents}

A very promising annual grass for hay, pasture or silos. A small patch we had made an average of 12 tons of dry hay, of good quality, per acre. It grows 6 feet high. If cut before it seeds, it will make a second crop, or a large amount of pasture.

Sow thin in rows 3 feet apart. Parties interested in stock should try it, as it promises to make several times as much feed per acre as other grasses. Seed cannot be had in quantities. 


\section{Land for Sale}

440 Acres at $\$ 18$ per acre, two miles from railroad, of extra rich dark level land, most of this has soil 10 feet deep, and cannot be excelled for Alfalfa. The alfalfa on the land joining made 9 tons per acre last season nad sold for $\$ 16$ per ton. It can be irrigated from a spring creek that runs through it.

$10-40$ Acre tracts at $\$ 17$ to $\$ 25$ per acre of rich level land, fine for Peaches, Pears, California Grapes, Alfalfa and English Walnuts. 40 acres of this land will bring in a larger income than 160 acres here with less expense.

The above land is in Toyah Valley of West Texas, which has an elevation of 3500 feet, which makes it a fine healthy climate, it all can be irrigated from a spring creek or shallow wells. We own several hundred acres in this valley, and feel sure that it will make high priced land.

4- 40 Acre tracts at $\$ 25$ per acre close to Pecos City, a city in the Pecos valley of 2000 population. Unlimited amount of shallow water under this land.

Louisiana Lands. We are agents for.a large tract of rich black level land, which is being cut up in farms to suit purchaser, and sold reasonable on very easy terms, they have plenty of rain, and grow large crops of Corn, Oats, Hay, and Pecans on this land. Corn made 149 bushels per acre near this land. Pamplets with photos, maps and prices, with full information furnished on application.

Iowa Land. Send for booklet describing 50 well improved farms 40 to 480 acres.

If you are interested in any of the above lands, send for descriptions of the ones you are interested in.

ALPHA NURSERY, Agents

Alpha, Illinois 


\section{4}

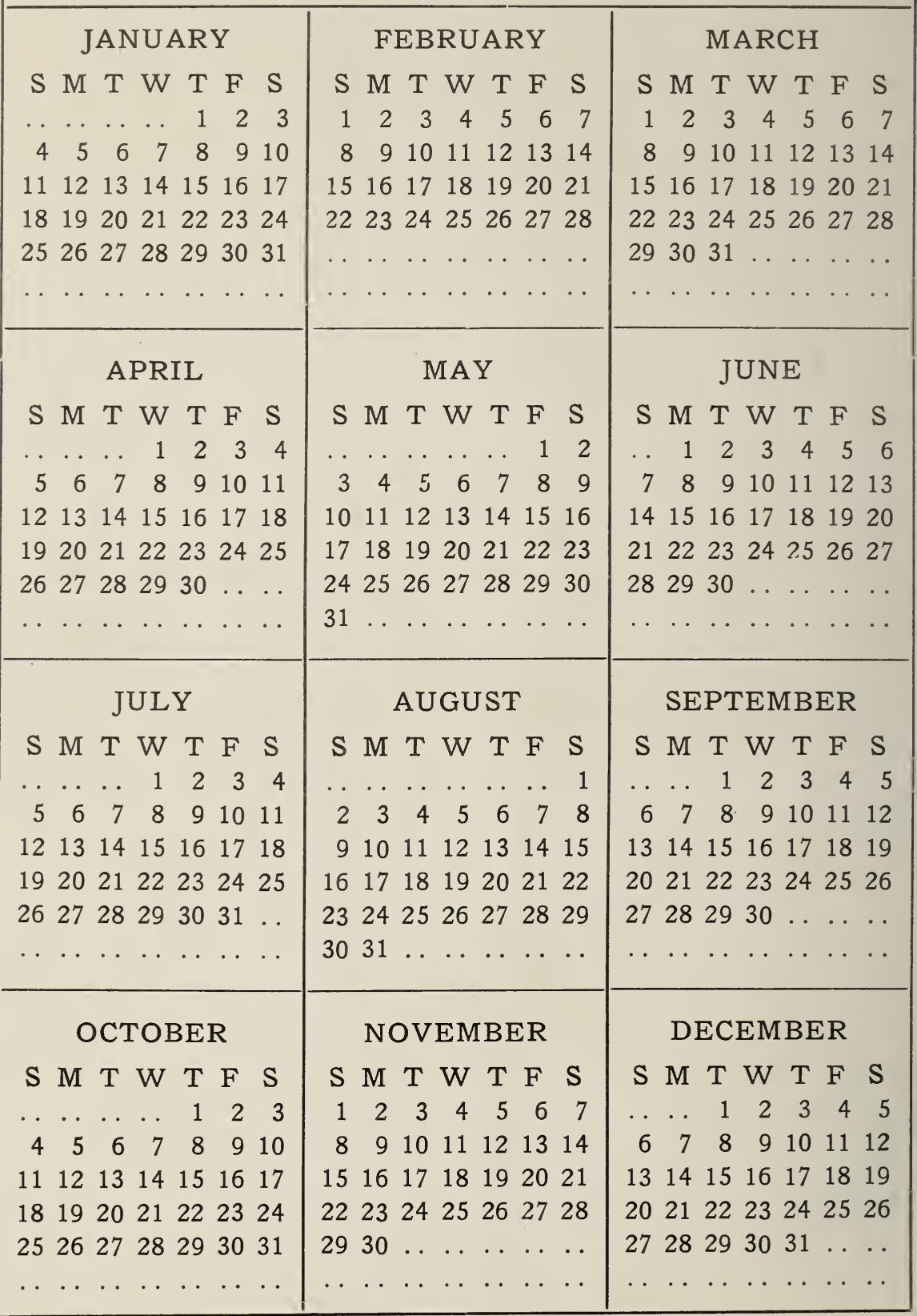

